\title{
Science experimental methods assisted video tutorials as an innovation for distance learning during COVID-19 pandemic
}

\author{
Melati Arifina Alanis *, Fina Indriyani, Anggraita Febriana Putri, Laifa Rahmawati \\ Universitas Negeri Yogyakarta. Jl. Colombo No. 1, Yogyakarta, 55281, Indonesia \\ Corresponding Author. Email: melatiarifina.2017@student.uny.ac.id
}

\section{Keywords:}

Science learning, experimental methods, student worksheets, video tutorials, distance education

\begin{abstract}
Science learning during COVID 19 pandemic had not been optimally implemented. This research aimed to discuss a new learning strategy, called science experimental accompanied by video tutorials as a distance learning innovation. A study literature method was used in this article. The experimental method was carried out in four stages, namely initial experiment, verification, concept application, and evaluation. This makes distance learning more effective and efficient. Students can develop thoughts, imaginations, and attitudes through exploration; foster interest and motivation to learn, and assisting in learning activities to achieve learning objectives without any limitations on distance and time. Demonstrations in this learning strategy can also be repeated and all students can understand the material.
\end{abstract}

C2021 JSER. Universitas Negeri Yogyakarta

\section{INTRODUCTION}

Distance Learning has been determined based on the Ministry of Education and Culture circular number 36962/MPK.A/HK/2020, in the context of preventing the development and spread of Coronavirus disease (COVID-19). Learning is carried out online from home for students. The Minister of Education and Culture Nadiem Makarim (2020) stated that the effectiveness of implementing distance learning during the pandemic was varied, some areas were considered quite effective, but there were still many that were considered not effective enough (Kementerian Pendidikan dan Kebudayaan Republik Indonesia, 2020). One reason is the opportunity for teachers and students to adapt to distance learning, which is quite short so that the learning process carried out was not optimal. There were still many activities of distance learning that takes place in one direction from the teacher to the students, namely in the form of providing materials or assignments. Based on the research by (Megawanti et al., 2020), the absence of real and close contacts with teacher and friends has made students unable to provide explanations, answers, and even a sense of happiness when undergoing distance learning from home.

The learning activities carried out should be able to provide insights for students about science. According to the Ministry of Education and Culture (2014) knowledge is a concept, theory, and method that has been structured so that it can be mastered through reasoning in the process of learning activities. One of the sciences that includes structured and systematic concepts, theories, and methods is natural science (Priyonggo \& Qosyim, 2018).

Aristiadi and Putra (2018) stated that science learning should be oriented towards activities that support the understanding of concepts, principles, and procedures related to the context of their daily lives. So, science learning will be more interesting and create effective learning activities. Science learning cannot be separated from experimental activities, but it is difficult to implement in distance learning. Based on Dale's cone of experience regarding learning activities, experiments can instill an understanding of $90 \%$ of what students do so that learning is more meaningful as well as the cognitive, affective, and psychomotor aspects of students can be achieved.

Science learning innovation is indispensable for distance learning activities. One of them is using an experimental video tutorial. The use of student worksheets and video tutorials can help students to carry out experimental activities. According to Utomo and Ratnawati (2018) video tutorials are a collection of live images that can present information provided by a tutor to others so that other people can understand the 
process or increase their knowledge by seeing the video. Wiguna (2016) stated that student worksheet is a guideline in learning to practice the development of cognitive aspects and other aspects of learning by experimenting.

Based on the problems that have been described above, it is necessary to conduct study literature related to science learning innovations during the COVID-19 pandemic to develop cognitive, affective, and psychomotor aspects of students through the use of experiments assisted by video tutorials. The purpose of this study is to examine experimental activities assisted by video tutorials as a distance learning innovation during the COVID-19 pandemic.

\section{METHOD}

The method used in conducting this research is literature study by exploring supporting theories. This research procedure is given by Zed (2004), namely (1) preparing the necessary equipment in this study, such as writing instruments, notes, internet, and a laptop needed to process data; (2) preparing a working bibliography, which is a record of sources used for research purposes obtained from e-books, scientific articles, and research journals related to distance learning, the COVID-19 pandemic, experiments, and video tutorials; (3) organizing the time, which in this case took one month to look for references, review, and analyze the data that had been collected; and (4) reading and recording research materials, i.e.: reading and assessing various sources of literature, then expressing the results of their thoughts through descriptive and argumentative writing.

\section{RESULT}

\section{Changes in Learning during the COVID-19 Pandemic}

Since the COVID-19 case in Indonesia, the government has restricted activities outside the home. From then on, there were changes in every sector of life, including the education sector. So that the learning patterns in Indonesia experiences a dynamic change called learning transformation. Learning activities before the pandemic hit were carried out face to face in person. However, after the pandemic occurred, distance learning was carried out both online and offline. The media commonly used in learning is demonstrated directly, but after the pandemic, information technology-based media was utilized. This change had occurred since the government issued a circular letter from the Ministry of Education and Culture number 36962/MPK.A/HK/2020 to curb the spread of COVID-19. This pandemic accelerates education 4.0, namely a learning system carried out remotely by utilizing information technology. G. Fortwengel, a Professor at the University of Applied Science and Arts, Hannover, Germany and Senior Experten Services (SES) Germany, explained that the corona outbreak was a great catalyst that spurred the world of education, e.g.: encouraging more use of information technology in distance learning activities. However, there are big challenges in the implementation of distance learning, namely teachers and students who are not ready because of sudden changes in the learning system. Teachers and students are not accustomed to implementing fully online learning so that the meaning and objectives of learning are not maximally achieved.

\section{Distance Learning}

Industrial revolution 4.0 requires us to be able to take advantage of information technology. This information technology can be implemented in distance learning. Information technology can overcome the limitations of distance and time within the reach of teachers and students.

Distance learning with the use of information technology can increase the independence, individuality, and autonomy of students in the learning process. Thompson (1990); Verduin Jr and Clark (1991) concluded that distance learning can be as effective as conventional learning if the methods and techniques used are following instructional tasks, such as there is an interaction between students and feedback between teachers and students. Distance learning is done offline and online. Based on the research by Megawanti et al. (2020), distance learning also allows students to easily answer via other sources such as Google. So those students are trained to learn actively.

The unpreparedness of teachers and students and the incompatibility of the methods used can hinder distance learning. Besides, students only tend to answer the assignments given by the teacher and do not understand the learning material they get. As expressed by Alam (2020) (Division of Curriculum Development and Foundation Assessment), the distance learning that is used now causes students to lose the opportunity to understand and to advance understanding. 


\section{Experimental Method}

The experimental method in science learning is conducted so that students can independently seek and find answers or problems faced through a scientific process. Through this method, students make observations to find out the truth of the theory they are studying (Oviana \& Maulidar, 2013). The learning process using the experimental method in distance learning activities is of course different from experimental activities in general. This is because the availability of tools and materials to support the learning process cannot be fully obtained.

Martho (2018) stated that learning with the experimental method includes the following stages: (1) initial experiments, namely experiments conducted by teachers or observing natural phenomena by displaying problems related to the material being studied, (2) verification, namely an initial activity for proving the initial guess through the formulation of experimental results and conclusions, (3) concept application, namely the application of learning concepts that have been learned, and (4) evaluation as the final stage of learning using the experimental method. Students can understand a learning concept if they can convey it verbally, in writing, or applying in everyday life.

The experimental method has the following advantages (1) truth or conclusions can be more trusted, (2) students can develop attitudes through an exploration of knowledge, and (3) provide breakthroughs as a result of experiments that are beneficial to their life. However, the experimental method also has disadvantages, namely: (1) the facilities in schools are limited so that not all students can carry out the experiments, (2) experiments require a long time to carry out, and (3) the experimental method is more suitable for the fields of science and technology.

The experimental method can be used in science learning. However, distance learning activities are less supportive if the experimental method is carried out normally, such as before the COVID-19 pandemic. So there is a need for learning innovation without eliminating the stages of experimental activity. The way that can be applied is that students do simple experiments using tools and materials available at home.

\section{Student worksheet and video tutorials}

The science learning process is needed by providing direct experience to students to build their knowledge. Direct experience can be realized with learning media that contains guidelines for students in carrying out scientific activities or problem-solving and question exercises. Especially in the distance learning process during this pandemic, learning media are needed to support the process of achieving learning objectives. Learning media is expected to make it easier for students to understand the knowledge they are learning (Hermawan et al., 2018; Lestari et al., 2018; Marsa et al., 2016; Putri \& Prodjosantoso, 2020). One of the learning media is the student worksheet. A student worksheet is sheets containing tasks that must be filled by students in the form of instructions and steps to complete a task according to the scientific approach, e.g. the process skills approach (Devi et al., 2021). Student worksheets can be used in activities experiments in the form of practicum instructions that use tools and materials or non-experiments by containing text that directs students to carry out individual activities or group discussions. The use of student worksheets can help students in learning activities to achieve learning objectives by the applicable curriculum by mastering aspects of understanding, skills, and attitudes so that learning becomes effective and efficient.

The video tutorial learning media can be used as an independent learning media for students as well as a fun learning tool and makes it easier for students to understand the material presented. Video tutorials made by the teacher can provide a clearer picture to students because they contain instructions and activity steps that must be carried out by students. The results of a research by Musthofa and Murdani (2018) state that the video tutorial learning media is proven to be effective in increasing the competence of students. Moreover, student worksheets can be modified by adjusting the characteristics of students, situations, and environmental conditions, and collaborating with video tutorial learning media which facilitates the learning process.

Setiawan (2017) states that the video in the learning process should be (1) in accordance with the learning objectives; (2) clear in the message conveyed; (3) familiar with its users; (4) representing the learning content; (5) able to be played repeatedly; and (6) able to be used classically or individually. Furthermore, (Munadi, 2013) stated that the advantages of video are as follows: (1) videos overcome distance and time limitations; (2) videos can be repeated as needed for clarity; (3) the messages conveyed by vidoes are fast and easy to remember; (4) videos can develop the mind and imagination of students; (5) vidoes provide a more realistic picture; (6) vidoes may strongly affects one's emotions; (7) videos are very 
good at explaining a process and a skill; (8) all students can learn from videos; and (9) vidoes can foster interest and motivation to learn.

\section{Experimental Methods assisted by Video Tutorials in Distance Learning}

The learning process with the experimental method is conducted by making an observation or experiment to find out the truth of the theory that is being studied. Then to achieve the learning objectives, it needs to be supported by other media. The student worksheet media includes activities that are carried out by students, which will be easier to understand if they are collaborated through video tutorials.

In the implementation of learning with the experimental method, equipment in laboratories is often used. However, distance learning cannot be supported by tools and materials available in the laboratory so that the experimental method is carried out at home using simple tools and materials at home. The stages of the experimental method carried out are given as follows. In the initial experiment, the teacher uses a video tutorial containing an example of an experiment that will be carried out as a demonstration for students. In the verification stage students try a simple experiment by themselves at home with the help of student worksheets and video tutorials that have been given by the teacher. In the application of concepts, students develop an example of an experiment that is tutored by the teacher using existing tools and materials at home. Students document the experiments carried out at home in the form of photos and videos. Finally, in the evaluation stage, the teacher provides an assessment and feedback to students based on the documentation that has been sent using various platforms, such as WA and google classroom.

The experimental methods in which there is a student worksheet assisted by video tutorials can simultaneously develop thoughts, imagination, and attitudes through exploration, foster interest and motivation to learn. These methods help students via learning activities to achieve learning goals in the cognitive, affective, and psychomotor domains so that learning becomes effective and efficient without limitations of distance and time. Moreover, the videos can be repeated and all students can understand the material.

\section{CONCLUSION}

The experiments assisted by video tutorials is a distance learning innovation during the COVID-19 pandemic, which makes learning activities more effective and efficient because students can develop thoughts, imaginations, and attitudes through exploration; and foster interest and motivation to learn. These mehods can assist learning activities to achieve learning objectives without any limitations on distance and time. Moreover, the demonstrations can be repeated so that students can understand the material.

\section{Proposition}

This paper still requires supporting literature so that readers can provide suggestions or input in order to make it better. Also, readers can develop these methods in junior high school science learning, such as simple airplane material and food testing.

\section{ACKNOWLEDGMENTS}

This work was supported mainly by the lecturers of the Science Education Program at Universitas Negeri Yogyakarta, hence the authors thank them for all their guidance and suggestions. The authors would also like to acknowledge the support of the committee that organized the National Science Education Webinar.

\section{REFERENCES}

Alam, S. (2020). Belajar di masa pandemi. Media Indonesia. https://mediaindonesia.com/opini/298260/belajar-di-masa-pandemi

Aristiadi, H., \& Putra, R. R. (2018). Pengaruh penggunaan lembar kerja peserta didik (LKPD) berbasis proyek terhadap hasil belajar peserta didik pada konsep pemanasan global. Bioedusiana: Jurnal Pendidikan Biologi, 3(2), 77-84. https://doi.org/10.34289/277886

Devi, V. M., Susilawati, S., \& Gunada, I. W. (2021). Pengembangan perangkat pembelajaran fisika model berbasis masalah pada materi elastisitas untuk meningkatkan kemampuan generik sains peserta didik. ORBITA: Jurnal Kajian, Inovasi Dan Aplikasi Pendidikan Fisika, 7(1), 109-114. https://doi.org/10.31764/orbita.v7i1.3822

Hermawan, H., Samsuri, S., Kurniawati, D. P., Sofyaningsih, V., \& Prasetyo, D. (2018). The use of controversial public issues with video and macromedia flash player media in civic education learning. 
Psychology, Evaluation, and Technology in Educational Research, 1(1), 19.

https://doi.org/10.33292/petier.v1i1.2

Kementerian Pendidikan dan Kebudayaan Republik Indonesia. (2020). Mendikbud kembali tegaskan pembukaan sekolah di zona hijau harus mengedepankan protokol kesehatan. Kemendikbud.Go.Id. https://www.kemdikbud.go.id/main/blog/2020/07/mendikbud-kembali-tegaskan-pembukaan-sekolahdi-zona-hijau-harus-mengedepankan-protokol-kesehatan

Lestari, T., Fajaruddin, S., \& Sacko, M. (2018). Developing booklet-type learning media for improving the students' learning results in computer application data processing course. Proceeding International Seminar, O(0). http://jurnal.ustjogja.ac.id/index.php/pep2019/article/view/3600

Marsa, M., Hala, Y., \& Taiyeb, A. M. (2016). Pengaruh penggunaan lembar kerja peserta didik berbasis pendekatan ilmiah terhadap aktivitas dan hasil belajar IPA biologi kelas VII peserta didik SMP Negeri 2 Watampone. Sainsmat: Jurnal Ilmiah Ilmu Pengetahuan Alam, 5(1).

Martho, M. (2018). Penerapan metode pembelajaran eksperimen untuk meningkatkan hasil belajar dan keterampilan proses sains peserta didik kelas X SMA Negeri 1 Cangkringan pada materi hukum Newton. Universitas Negeri Yogyakarta.

Megawanti, P., Megawati, E., \& Nurkhafifah, S. (2020). Persepsi peserta didik terhadap PJJ pada masa pandemi Covid 19. Faktor: Jurnal Ilmiah Kependidikan, 7(2), 75-82.

https://doi.org/10.30998/fjik.v7i2.6411

Munadi, Y. (2013). Media pembelajaran (Sebuah pendekatan baru). Bumi Aksara.

Musthofa, U., \& Murdani, M. (2018). Efektivitas penggunaan media pembelajaran video tutorial untuk meningkatkan kompetensi menggambar 3D. Jurnal Pendidikan Teknik Mesin, 18(2). https://journal.unnes.ac.id/nju/index.php/JPTM/article/view/18662

Oviana, W., \& Maulidar, M. (2013). Penggunaan metode eksperimen pada pembelajaran materi sifat bahan dan kegunaannya terhadap hasil dan respon belajar siswa kelas IV MIN Tungkob Aceh Besar. Jurnal Ilmiah Didaktika, 13(2). https://doi.org/10.22373/jid.v13i2.482

Priyonggo, F. V., \& Qosyim, A. (2018). Pengembangan media pembelajaran interaktif berbasis macromedia flash untuk materi sistem gerak pada manusia kelas VIII. Pensa E-Jurnal: Pendidikan Sains, 6(02). https://jurnalmahasiswa.unesa.ac.id/index.php/pensa/article/view/23383

Putri, M. A., \& Prodjosantoso, A. K. (2020). Improving critical thinking skills and scientific attitudes by using comic. Psychology, Evaluation, and Technology in Educational Research, 2(2), 69. https://doi.org/10.33292/petier.v2i2.13

Setiawan, Y. (2017). Pengembangan video tutorial pemanfaatan perangkat wiimote whiteboard bagi guru dalam membelajarkan fisika. Universitas Lampung.

Thompson, G. (1990). How can correspondence-based distance education be improved? A survey of attitudes of students who are not well disposed toward correspondence study. Journal of Distance Education, 5(1), 53-65. http://www.ijede.ca/index.php/jde/article/download/371/262?inline=1

Utomo, A. Y., \& Ratnawati, D. (2018). Pengembangan video tutorial dalam pembelajaran sistem pengapian di SMK. Jurnal Taman Vokasi, 6(1), 68-76.

Verduin Jr, J. R., \& Clark, T. A. (1991). Distance education: The foundations of effective practice. JosseyBass.

Wiguna, M. C. (2016). Pengembangan LKPD IPA berbasis keterampilan proses untuk meningkatkan sikap ilmiah dan minat siswa SMP. Jurnal Pendidikan Matematika Dan Sains, 4(2), 176-183. https://doi.org/10.21831/jpms.v4i2.12441

Zed, M. (2004). Metode penelitian kepustakaan. Yayasan Obor Indonesia. 